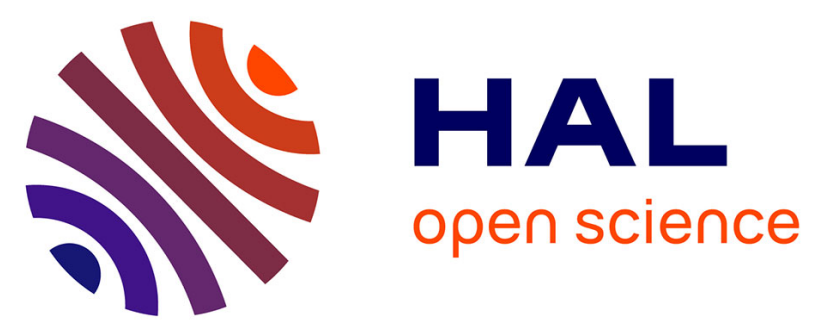

\title{
Nitrogen fixation and growth of Lens culinaris as affected by nickel availability: A pre-requisite for optimization of gromining
}

Ramez Saad, A. Kobaissi, Christophe Robin, Guillaume Echevarria, E Benizri

\section{- To cite this version:}

Ramez Saad, A. Kobaissi, Christophe Robin, Guillaume Echevarria, E Benizri. Nitrogen fixation and growth of Lens culinaris as affected by nickel availability: A pre-requisite for optimization of gromining. Environmental and Experimental Botany, 2016, 131 (Environmental and Experimental Botany), pp.1-9. 10.1016/j.envexpbot.2016.06.010 . hal-01458433

\section{HAL Id: hal-01458433 https://hal.science/hal-01458433}

Submitted on 6 Feb 2017

HAL is a multi-disciplinary open access archive for the deposit and dissemination of scientific research documents, whether they are published or not. The documents may come from teaching and research institutions in France or abroad, or from public or private research centers.
L'archive ouverte pluridisciplinaire HAL, est destinée au dépôt et à la diffusion de documents scientifiques de niveau recherche, publiés ou non, émanant des établissements d'enseignement et de recherche français ou étrangers, des laboratoires publics ou privés. 


\title{
Nitrogen fixation and growth of Lens culinaris as affected by nickel availability: A pre-requisite for optimization of agromining
}

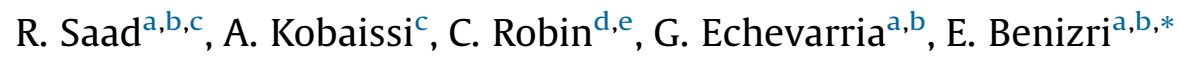 \\ a Université de Lorraine, Laboratoire "Sols et Environnement”, UMR 1120, Vandœuvre-lès-Nancy, F-54518, France \\ b INRA, Laboratoire “Sols et Environnement", UMR 1120, Vandœuvre-lès-Nancy, F-54518, France \\ 'Université Libanaise, Laboratoire "Biologie Végétale et Environnement", Faculté des Sciences 1, Beyrouth, Lebanon \\ 'Université de Lorraine, Laboratoire "Agronomie et Environnement" Nancy-Colmar, UMR 1121, Vandœuvre-lès-Nancy, F-54518, France \\ e INRA, Laboratoire "Agronomie et Environnement" Nancy-Colmar, UMR 1121, Vandœuvre-lès-Nancy, F-54518, France
}

\section{A R T I C L E I N F O}

\section{Article history:}

Received 11 March 2016

Received in revised form 13 June 2016

Accepted 16 June 2016

Available online 23 June 2016

\section{Keywords:}

Nitrogen fixation

Lens culinaris

Soil fertility

Agromining

Nickel
A B S T R A C T

Low soil fertility in ultramafic soils limits the efficiency of nickel phytoextraction. Developing more efficient cropping systems for agromining can be achieved by the association of a hyperaccumulator with a legume by enhancing soil fertility. However, legume crops can result sensitive to ultramafic soil conditions, including nickel $\mathrm{Ni}$ availability. We assessed here whether Lens culinaris is adapted to ultramafic environments by growing on soils displaying a wide range of $\mathrm{Ni}$ concentrations and consequently producing functional nodules. The soil was enriched with different Ni concentrations ([Ni]) (0-90 mg Ni kg ${ }^{-1}$ ). Natural ${ }^{15} \mathrm{~N}$ abundance was used to assess $\mathrm{N}_{2}$ fixation (\%Ndfa). Biotic parameters were investigated (nodule number, $\mathrm{Ni}$, carbon and nitrogen concentrations, plant biomass...). Soil parameters were investigated (total [Ni], DTPA-extractable $\mathrm{Ni}, \mathrm{C}$ and $\mathrm{N}$ concentrations ... ). Most of the physicochemical and biological parameters were significantly affected by the increased soil [Ni]. Nodule numbers per plant was lower under high [Ni] than control (soil without $\mathrm{Ni}$ ). Nodules lost their capacities to fix $\mathrm{N}_{2}$ under high $\mathrm{Ni}$ addition $\left(90 \mathrm{mg} \mathrm{Ni} \mathrm{kg}^{-1}\right)$. For many parameters, there were no significant differences between control and treatments up to $60 \mathrm{mg}$ of $\mathrm{Ni} \mathrm{kg}^{-1}$ added to the soil. Lentil is able to grow on a soil containing amounts of Ni-DTPA similar to those generally found in serpentine soils. It could be used in association with a hyperaccumulator plant as a nitrogen provider in order to optimize $\mathrm{Ni}$ agromining.

(c) 2016 Elsevier B.V. All rights reserved.

\section{Introduction}

Serpentine soils (i.e. ultramafic soils) are derived from ultramafic rocks and contain significant amounts of metallic trace elements (MTE) including copper, chromium, iron, titanium, cobalt and nickel (Berazaín, 2007; Chaney et al., 2008). The average total content of nickel $(\mathrm{Ni})$ in these soils under temperate to Mediterranean conditions can range between 1400 and 3500 ppm (Kabata-Pendias, 2000; Bani et al., 2014). Ultramafic soils are also characterized by high $\mathrm{Mg}$ concentrations and a deficiency in N, P, K and Ca (Kabata-Pendias, 2000; Boyd and Jaffré, 2009). As a result of the presence of heavy metals, very high $\mathrm{Mg}: \mathrm{Ca}$ ratio (Bani et al., 2007) and deficiencies, serpentine soils are entirely ill-suited to profitable agricultural production and even

\footnotetext{
* Corresponding author at: Université de Lorraine, Laboratoire "Sols et Environnement", UMR 1120, Vandœuvre-lès-Nancy, F-54518, France.

E-mail address: emile.benizri@univ-lorraine.fr (E. Benizri).
}

forests (Tumi et al., 2012). Their low-fertility and low-productivity make them unattractive for traditional agriculture and many of these areas are slowly abandoned by farmers, with rural exodus and landscape closure. However, serpentine outcrops in Europe cover over $10,000 \mathrm{~km}^{2}$ and these ultramafic landscapes have potential to provide multiple ecosystem services and contribute to Europe's goals towards insuring production of renewable raw materials and renewable energy (Echevarria et al., 2015). The idea of phytomining metals emerged in the 90 s (Chaney et al., 2007) and the goal was to cultivate plants able to accumulate trace metals from metal-rich soils and transport them to the shoots $(>1 \%)$, which could then be harvested as a bio-ore to recover highly valuable metals, e.g. nickel (Ni). Nickel-hyperaccumulating plants are considered ideal candidates for agromining, which is a nondestructive approach to the recovery of high value metals (e.g. Ni) from metal-enriched soils and ores (van der Ent et al., 2013, 2015). In Europe, about 40 endemic taxa of Ni-hyperaccumulators from two families (Brassicaceae and Asteraceae) can be found. The 
process involves root uptake of trace metals from soils, as well as their active transport to the shoots where they can be extracted after harvest (Chaney et al., 2008). Phytomining was proven to be efficient in the 2000s and became a real market opportunity in 2007 (Chaney et al., 2007; Tang et al., 2012). Few works described the implementation of agroecosystems which can lead to better soil resource efficiency and to offer fully integrated, new phytomining agriculture that could cover thousands of $\mathrm{km}^{2}$ in Europe and benefit local communities with sustainable rural development (Bani et al., 2007, 2015a,b). The recent development of the phytomining concept led to the definition of "agromining" (van der Ent et al., 2015) as a way to provide multiple ecosystem services, such as provisioning services (e.g. metal, fuel-biomass) and supporting services (e.g. amelioration of the fertility of ultramafic soils over time). In this context, the use of the $\mathrm{Ni}$ hyperaccumulator Alyssum murale was proven to be economically feasible in Europe (Albania) based on successful field experiments (Bani et al., 2007, 2015a,b). However, several bottlenecks have been identified and need to be solved before agromining fully develops in Europe. In particular, ultramafic soils showed low-fertility and low-productivity, thus fertilizer amendments such as $\mathrm{N}, \mathrm{P}$ and $\mathrm{K}$ must be considered to significantly improve crop growth and phytoextraction yield (Bani et al., 2015a; Kidd et al., 2015). Moving towards agromining would result in a more resource-friendly agriculture, i.e. agro-ecological practices should be introduced as a substitute to conventional fertilization and pest-control practices.

As shown with cereal food crops, forage, silvo-pastoral, agroforestry and horticultural systems, the inclusion of a legume in inter-cropping or co-cropping provides nitrogen inputs in the cultural system in addition to producing valuable yields (Lizarazo et al., 2015; Peoples et al., 2015). Indeed, it is known that legumes, used in either inter-cropping or co-cropping, influence the $\mathrm{N}$ economy of a system in two ways: they fix part of their $\mathrm{N}$ requirement from atmospheric $\mathrm{N}_{2}$ and, therefore, deplete available soil-N lesser than non-legumes, and also provide part of the fixed$\mathrm{N}$ upon mineralization of decaying plant residues to the nonleguminous crop (Nyagumbo et al., 2015; Peoples et al., 2015). Moreover, in traditionnal agronomy, legume cover crops are used to reduce or prevent erosion, produce biomass and add organic matter to the soil, attract beneficial insects and they can break weed-, disease- and insect-cycles. Therefore, inter-cropping or cocropping hyperaccumulator plants with legumes could improve phytoextraction yield through the enrichment of ultramafic soils with nitrogen fixed from the air. A part of the $\mathrm{N}$ fixed being usually transferred to companion plants (Rodrigues et al., 2015), the hyperaccumulator could benefit from this biological process, while reducing fertilizer inputs and pesticides to the field. The combination of a legume species with a hyperaccumulator plant could be an innovative strategy for agromining; if the legume tolerates high metal concentration, it could lead to higher hyperaccumulator biomass and reduce the amount of fertilizer supplied, combining higher economic performance and lower environmental impact (Scalise et al., 2015; Luce et al., 2015). Thus, $\mathrm{N}$ biological fixation can act as a primary $\mathrm{N}$ source (biofertilizer) and provide an ecosystem service, thereby complementing or replacing fertilizer inputs (Fustec et al., 2010; Mokgehle et al., 2014).

Among the factors that reduce plant growth and crop yield in ultramafic soils (i.e. the Serpentine syndrome) we can list (Whittaker 1954; Proctor and Woodell 1975; Brooks 1987): Mg excess over Ca; K, P and Ca deficiency; Ni toxicity. Growing nonadapted legumes in ultramafic conditions could then result in a reduction of beneficial effect of co-cropping because of these factors. Specific amendments can help the plant face the nutrient unbalances. But the presence of metals (in our case $\mathrm{Ni}$ ) in soil could limit the growth of non-hyperaccumulator species and stimulate the production of ethylene in plants (Abeles et al., 1992; Glick, 2005; Glick, 2014), which affects root growth and nodule formation in legumes such as beans, peas, clovers and vetches (Ligero et al., 1991; Lee and Larue, 1992; Hirsch and Fang, 1994).

Hence, our objective was to investigate whether Lens culinaris, a legume, could be used in inter- or co-cropping with a hyperaccumulator plant, on a natural ultramafic Ni-rich soil, in order to improve $\mathrm{Ni}$ phytoextraction by the hyperaccumulator plant without any chemical fertilizer inputs. The first step is to confirm if this legume can grow and form nodules on a soil containing varied $\mathrm{Ni}$ concentrations. We assessed whether these nodules fix nitrogen in the presence of $\mathrm{Ni}$. This study is a prerequisite for using Lens culinaris in inter- or co-cropping with a hyperaccumulator plant, on a natural ultramafic Ni-rich soil, in order to improve $\mathrm{Ni}$ phytoextraction. Our strategy was to grow lentils on soil artificially enriched with $\mathrm{Ni}$ and then to estimate nitrogen fixation by natural ${ }^{15} \mathrm{~N}$ abundance because using a serpentine soil does not allow assessing the effect of each of the factors that generate the serpentine syndrome. We chose an agricultural Ni-enriched soil in which we carefully added $\mathrm{Ni}$ in order to reach the same DTPAavailable concentrations of $\mathrm{Ni}$ than those we currently found in the ultramafic soils (e.g. Albania) where we pretend to crop $L$. culinaris $+A$. murale. Then, we will be able to estimate if lentil will be a good candidate for co-cropping or rotation with a hyperaccumulator plant.

\section{Material and methods}

\subsection{Soil characteristics and experimental design}

We performed a two month microcosm study in controlled conditions (photoperiod $16 \mathrm{~h}$, temperature $18^{\circ} \mathrm{C}$ night and $22^{\circ} \mathrm{C}$ day, relative humidity 70\%, PPFD: $350 \mu \mathrm{mol} \mathrm{m}^{-2} \mathrm{~s}^{-1}$ ) based on three treatments: lentil sown in soil with increasing Ni concentrations, ryegrass sown in soil with increasing Ni concentrations and lentil sown in sand also with increasing Ni concentrations. The soil used in this experiment was an agricultural topsoil, collected from the surface layer $(10-20 \mathrm{~cm})$, originating from "La Bouzule" Experimental Farm of Université de Lorraine $\left(48^{\circ} 44^{\prime} 22.27^{\prime \prime} \mathrm{N}\right.$, $6^{\circ} 19^{\prime} 19.85^{\prime \prime} \mathrm{E}$, Meurthe et Moselle, France) and previously cultivated with nodulated pea, thus naturally containing Rhizobium leguminosarum. Immediately after collection, the soil was sieved to $<5 \mathrm{~mm}$ to remove coarse fragments and stored at $4{ }^{\circ} \mathrm{C}$ for less than 7 days until soil physicochemical analyses were carried out. Soil physicochemical properties were determined by the Soil Analysis Laboratory of INRA (Arras, France). It contained 36.7, 51.5 and $7.2 \%$, clay, silt and sand respectively had a $\mathrm{C} / \mathrm{N}$ ratio of $9.2, \mathrm{a} \mathrm{Mg} /$ Ca ratio of 0.08 and an available phosphorus content (Olsen P) of 63 $\mathrm{mg} \cdot \mathrm{kg}^{-1}$. Soil $\mathrm{pH}$ was 6.4 and was similar (less than 1 unit difference) with the ultramafic soils targeted for field implementation of agromining with legume co-cropping in Albania and Northwestern Spain (pH range from 6.0 to 7.0). Total $\mathrm{Ni}$ and available Ni (DTPA-extractable) contents were respectively $67.5 \mathrm{mg}$ $\mathrm{Ni} \mathrm{kg}^{-1}$ and $1.8 \mathrm{mg} \mathrm{Ni} \mathrm{kg}^{-1}$. We artificially enriched the soil with nickel sulfate $\left(\mathrm{NiSO}_{4}, 7 \mathrm{H}_{2} \mathrm{O}\right)$ with six different concentrations $(0$, $10,20,30,60$ and $90 \mathrm{mg} \mathrm{Ni} \mathrm{kg}^{-1}$ dry soil). The soil was then incubated for 15 days prior to sowing plants to avoid major changes in Ni availability during plant growth and have them occur before. Our goal was to keep the gradient of available $\mathrm{Ni}$ in a range that included $30 \mathrm{mg} \mathrm{Ni} \mathrm{kg}^{-1}$, which is the value that was measured on two field sites where legumes will be grown together with Alyssum murale. Microcosms (Polyvinyl chloride tubes, $4.7 \mathrm{~cm}$ diameter and $22 \mathrm{~cm}$ height) were filled with $416.2 \mathrm{~g}$ of soil (on the DW basis). One lentil or ryegrass seed was sown in each microcosm. Lentil seeds were provided by Sem-Patners (Lens culinaris var. Beluga, France) 
and ryegrass seeds by Forum (Lolium multiforum L. italicum. France). A set of microcosms were filled with sand, previously enriched with the six nickel sulfate concentrations. Lentils cultivated on sand and inoculated with a Rhizobium strain, were used as controls for quantification of $\mathrm{N}_{2}$ fixation (see below). Seeds on sandy substrate were disinfected by immersion in ethanol $95 \%$ for $30 \mathrm{~s}$, followed by immersion for $10 \mathrm{~min}$ in a hydrogen peroxide solution $\left(\mathrm{H}_{2} \mathrm{O}_{2}, 3 \%\right)$. The seeds were then rinsed at least five times with sterile distilled water. Before enriched with nickel sulfate, the sand was washed with hydrochloric acid (N/3, incubation for $12 \mathrm{~h}$ followed by several rinses with distilled water) in order to mineralize the organic matter residues. Then, each sandy microcosm was inoculated with a Rhizobium strain. We used the self-adhering peat-based inoculant for Lentil (Becker Underwood, Canada). This product contains at least $10^{9}$ viable cells of Rhizobium leguminosarum biovar viciae strain 1435 per gram and we brought $1.2 \mathrm{~kg}$ per $600 \mathrm{~kg}$ seed, in accordance with manufacturer's instructions.

The experiment had a randomized complete block design with three replicates of the following treatments: lentil and ryegrass cultivated on the Ni-enriched agricultural soil and lentil (inoculated with Rhizobium) cultivated on Ni-enriched sand. The Nicontaminated agricultural soils were adjusted three times per week to $70 \%$ of soil water holding capacity with distilled water. Lentils on sand were irrigated with a nutrient solution without nitrogen (pH 6.98) (Munns, 1977).

\subsection{Plant analyses}

After 2 months of culture, plant roots, stems and leaves were collected and separated. Fresh roots were carefully washed with deionized water and the nodule number per plant was counted by microscopic observations. Then, roots and shoots parts were ovendried at $70^{\circ} \mathrm{C}$ for $72 \mathrm{~h}$ and dry weights recorded. Subsamples $(0.5 \mathrm{~g})$ of dry and ground plant tissue were acid-digested at $95^{\circ} \mathrm{C}$ in $2.5 \mathrm{ml}$ of concentrated $\mathrm{HNO}_{3}$ and $5 \mathrm{ml}$ of $\mathrm{H}_{2} \mathrm{O}_{2}$ (30\%). The final solutions were filtered ( $0.45 \mu \mathrm{m}$ DigiFILTER) and completed up to $25 \mathrm{ml}$ with deionized water. [Ni] in the solution was measured with an Inductively Coupled Plasma-Atomic Emission Spectrometer (ICPAES, Liberty II, Varian).

Metals are known to cause severe toxicity to various metabolic activities of legumes, including physiological processes like synthesis of chlorophyll pigments (Bibi and Hussain, 2005; Ahmad et al., 2008) and protein synthesis (Brahima et al., 2010). Heavy metals are known for their inhibition of nitrate reductase activity (NRA) (Fatnassi et al., 2014). Consequently, total chlorophyll, carotenoid concentrations and nitrate reductase activity in the leaves were assessed as indicators of the $\mathrm{Ni}$ effects on plant physiology. Chlorophyll and carotenoids were extracted by incubation of leaves in acetone $(80 \%)$ for $24 \mathrm{~h}$ followed by measurements of optical density using a SmartSpec Plus Spectrophotometer, BIO-RAD (wave lengths of 663,645 and $440 \mathrm{~nm}$ for chlorophyll a, b and carotenoids, respectively). The respective concentrations of chlorophyll a and b were calculated according to Arnon (1949). The potential NRA was estimated in fresh leaves by incubation in $0.1 \mathrm{M}$ phosphate buffer ( $\mathrm{pH} 7.5$ ), $30 \mathrm{mM} \mathrm{KNO}_{3}$, and $5 \%$ isopropanol at $28^{\circ} \mathrm{C}$ for $2 \mathrm{~h}$, followed by the addition of sulfanilamide $3 \mathrm{M} \mathrm{HCl}$ and $0.02 \%$ naphthylethylene diamine hydrochloride (NED HCl). The mixture was left for $20 \mathrm{~min}$ for maximum color development prior to optical density measurement with a spectrophotometer (SmartSpec Plus Spectrophotometer, BIO-RAD) at $540 \mathrm{~nm}$ (Jaworski, 1971). The total C and $\mathrm{N}$ in the plant parts were analyzed by combustion at $900^{\circ} \mathrm{C}$ with an analyzer C, N (vario MICRO cube, Elementar Analysensysteme $\mathrm{GmbH}$ ).
We used the ${ }^{15} \mathrm{~N}$ natural abundance $\left(\delta^{15} \mathrm{~N}\right)$ technique (Kerley and Jarvis, 1999) to estimate the proportion of $\mathrm{N}$ (\%Ndfa) in lentils derived from biological nitrogen fixation (BNF). We used ryegrass (Lolium perenne L.) grown in pots contaminated with $\mathrm{Ni}$ in the same way as the lentils, as non-legume (non-fixing) control plants to estimate $\delta^{15} \mathrm{~N}$ of the $\mathrm{N}$ uptake from soil. Finally, we used lentils grown on sandy substrate and inoculated with a Rhizobium strain to estimate the $\delta^{15} \mathrm{~N}$ of the legume when fixing $100 \%$ of $\mathrm{N}_{2}$ (Amarger et al., 1979; Högberg, 1997). The \%Ndfa was calculated using the following equation:

$\% \mathrm{Ndfa}=\frac{\left(\delta^{15} \mathrm{~N} \text { of Ryegrass }-\delta^{15} \mathrm{~N} \text { Lentil }\right)}{\left(\delta^{15} \mathrm{~N} \text { of Ryegrass }-\delta^{15} \mathrm{~N} \text { Lentil on sand }\right)} \times 100$

Then, the amount of Ndfa per plant was calculated by multiplying the \%Ndfa by the lentil biomass for each plant. Nitrogen originating from the seeds was quantified, by measuring total $\mathrm{N}$ and $\delta^{15} \mathrm{~N}$.

\subsection{Soil analyses}

Soil moisture was determined by heating subsamples to $105^{\circ} \mathrm{C}$ until a constant weight was achieved. Subsamples $(0.5 \mathrm{~g})$ of dry soil were acid-digested in $2 \mathrm{ml}$ of concentrated $\mathrm{HNO}_{3}$ and $6 \mathrm{ml}$ of concentrated $\mathrm{HCl}$ for quantification of major and trace elements. The final solutions were filtered $(0.45 \mu \mathrm{m}$ DigiFILTER, SCP science, Canada) and completed up to $50 \mathrm{ml}$ with deionized water. [Ni] in the solution was measured with an Inductively Coupled PlasmaAtomic Emission Spectrometer (ICP-AES, Liberty II, Varian). Available Ni in soil samples from each microcosm was extracted with a DTPA-TEA solution (0.005 M Diethylene Triamine Pentaacetic Acid, DTPA, $0.01 \mathrm{M} \mathrm{CaCl}_{2}, 0.1 \mathrm{M}$ triethanolamine, pH 7.3) according to Lindsay and Norvell (1978) and the [Ni] in solutions was measured with an ICP-AES (Liberty II, Varian). The CEC was measured according to international ISO standard 23470 . Soil pH was measured using a $\mathrm{pH}$ meter in a soil-water suspension (soil: water ratio $=1: 5$ ).

Total and organic $\mathrm{C}$ and $\mathrm{N}$ were quantified with the $\mathrm{C}, \mathrm{N}$ Analyzer. Soluble $\mathrm{C}$ and $\mathrm{N}$ were determined on $5 \mathrm{~g}$ of dried soil extracted with $25 \mathrm{ml}$ of $\mathrm{CaCl}_{2}(1 \mathrm{mM})$ by agitation at $5 \mathrm{rpm}$ for $24 \mathrm{~h}$. The mixture was then filtered through a Whatman filter (nylon membrane, $0.45 \mu \mathrm{m}$ ) and soluble $\mathrm{C}$ and $\mathrm{N}$ of $\mathrm{CaCl}_{2}$ solutions were then analyzed with a TOC analyzer (TOC-VSCN equipment, Shimadzu, Kyoto, Japan). Nitrate and ammonium ions were quantified on $15 \mathrm{~g}$ of fresh soil mixed to $75 \mathrm{ml}$ of $0.016 \mathrm{M} \mathrm{KH}_{2} \mathrm{PO}_{4}$ and stirred for $30 \mathrm{~min}$ at $17 \mathrm{rpm}$. The soil suspension was then

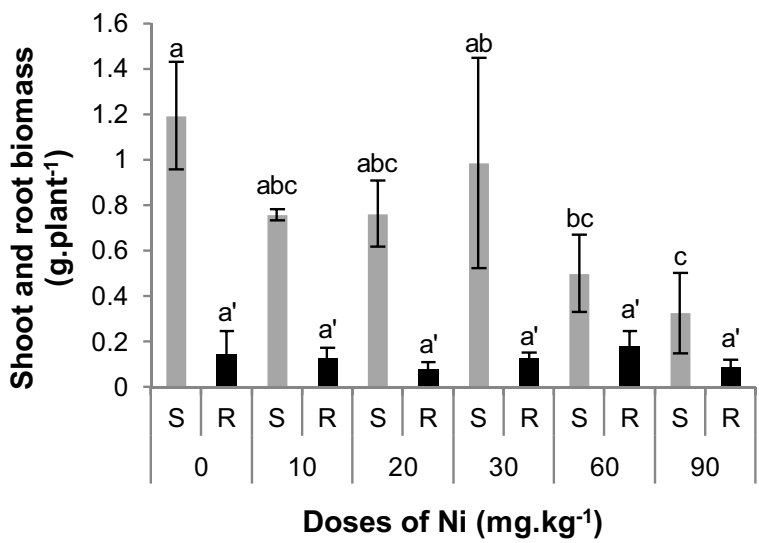

Fig. 1. Shoot (grey bars) and root (black bars) biomass (g plant ${ }^{-1}$ ) of lentils in relation to $\mathrm{Ni}$ additions $\left(\mathrm{mg} \mathrm{kg}^{-1}\right)$. Means \pm confidence interval followed by different letters are significantly different at $\mathrm{p}<0.05$ (Tukey's multiple range test), $(n=3)$. 


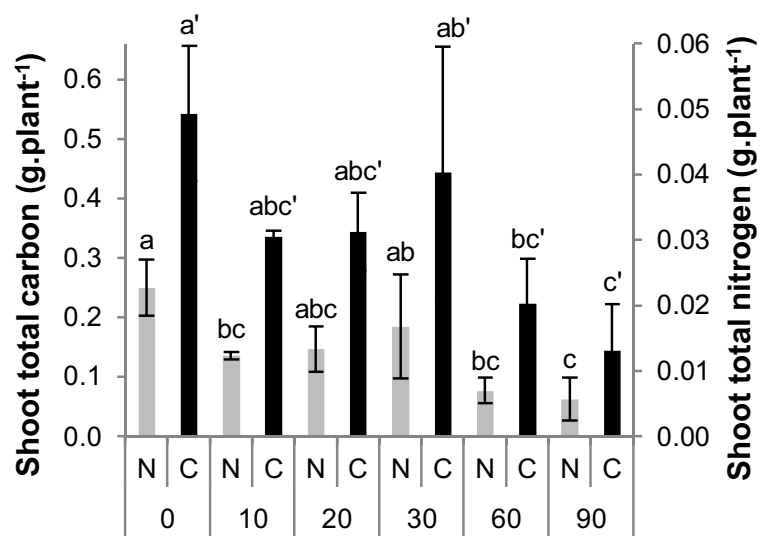

\section{Doses of Ni $\left(\mathrm{mg}^{\mathrm{kg}}{ }^{-1}\right)$}

Fig. 2. Total nitrogen (N: grey bars) and carbon (C: black bars) in shoots of lentils ( $g$ plant $^{-1}$ ) grown on soil contaminated with $\mathrm{Ni}$. Means \pm confidence interval followed by different letters are significantly different at $\mathrm{p}<0.05$ (Tukey's multiple range test), $(n=3)$.

centrifuged (20 min at $5800 \mathrm{~g}$ ) and filtered through a Whatman filter (nylon membrane, $0.45 \mu \mathrm{m}$ ) before analysis by Ion Chromatography (Dionex 1500i with an AS 4 ASC column; Sunnyvale, USA).

\subsection{Statistical analyses}

Variance analysis was carried out on all data using one-way ANOVA (Tukey test with a confidence interval of 95\%). Also, normality tests and k-sample comparison of variances were analyzed. These statistical analyses were carried out on XLSTAT software (XLSTAT 2015.2.01.16520, http://www.xlstat.com). Furthermore, all the parameters studied were submitted to PCA using StatBox software (Grimmersoft, Paris, France, http://www.statbox. com).

\section{Results}

\subsection{Plant analyses}

\subsubsection{Shoot and root biomass}

Lentils from treatment without $\mathrm{Ni}\left(0 \mathrm{mg} \mathrm{Ni} \mathrm{kg}{ }^{-1}\right)$ had the greatest shoot dry biomass $(1.19 \mathrm{~g})$ when compared to other treatments (Fig. 1). There was no significant difference for the

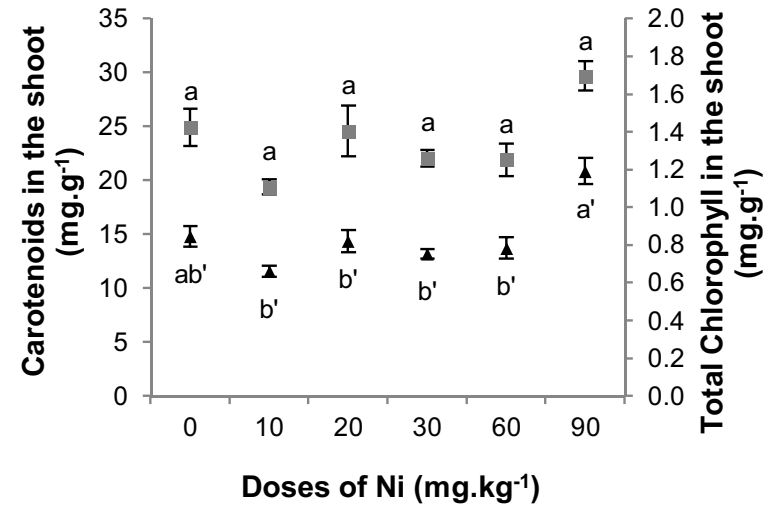

Fig. 4. Carotenoid (grey squares) and chlorophyll (black triangles) concentrations in leaves of lentils $\left(\mathrm{mg} \mathrm{g}^{-1} \mathrm{FW}\right)$ grown on soil contaminated with Ni. Means \pm confidence interval followed by different letters are significantly different at $\mathrm{p}<0.05$ (Tukey's multiple range test), $(n=3)$.

shoot dry biomass from 0 (control) up to $30 \mathrm{mg} \mathrm{Ni} \mathrm{kg}^{-1}$. Treatment with $90 \mathrm{mg} \mathrm{Ni} \mathrm{kg}^{-1}$ showed the smallest shoot biomass $(0.32 \mathrm{~g})$, significantly lower than that of the control. The root dry weight was not affected by $\mathrm{Ni}$ addition.

\subsubsection{Carbon and nitrogen content in shoots and roots}

Total $\mathrm{N}$ and $\mathrm{C}$ in plant shoots were similarly affected by increasing soil [Ni] (Fig. 2). The control treatment had the highest values ( 0.02 and $0.54 \mathrm{~g}$ plant $^{-1}$ of total $\mathrm{N}$ and total $\mathrm{C}$, respectively) and the $90 \mathrm{mg} \mathrm{Ni} \mathrm{kg}^{-1}$ treatment the lowest values ( 0.01 and $0.14 \mathrm{~g}$ plant $^{-1}$ of total $\mathrm{N}$ and total $\mathrm{C}$, respectively). There were no significant differences among other treatments. There was no significant effect of soil [Ni] on total $\mathrm{N}$ in the roots (data not

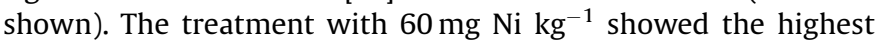
amount of total $C$ in roots $\left(0.12 \mathrm{~g} \mathrm{plant}^{-1}\right)$ with a significant difference to all other treatments (data not shown).

\subsubsection{Ni concentrations in shoots and roots}

The total $\mathrm{Ni}$ concentrations in lentil shoots and roots significantly increased when soil $\mathrm{Ni}$-concentrations increased (Fig. 3). [Ni] was $34 \mathrm{mg} \mathrm{Ni} \mathrm{kg}{ }^{-1} \mathrm{DW}$ in shoots for the highest soil [Ni] of $90 \mathrm{mg} \mathrm{Ni} \mathrm{kg}^{-1}$. Unsurprisingly, roots accumulated much more Ni than the shoots, with $172 \mathrm{mg} \mathrm{Ni} \mathrm{kg}^{-1}$ in the soil treatment

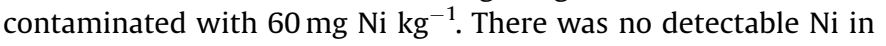

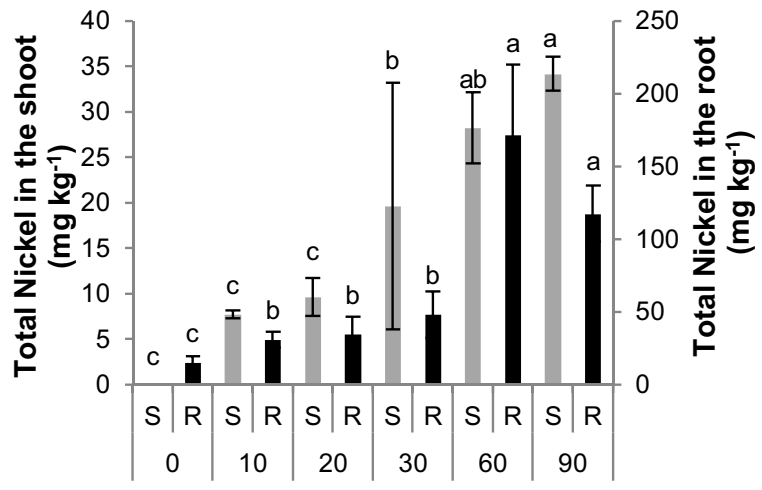

Doses of $\mathrm{Ni}\left(\mathrm{mg}^{\mathrm{kg}}{ }^{-1}\right)$

Fig. 3. Total Ni concentration in shoots (S: grey bars) and roots (R: black bars) $\left(\mathrm{mg} \mathrm{kg}^{-1} \mathrm{DW}\right)$ of lentils in relation to $\mathrm{Ni}$ additions $\left(\mathrm{mg} \mathrm{kg}^{-1}\right)$. Means \pm confidence interval followed by different letters are significantly different at $\mathrm{p}<0.05$ (Tukey's multiple range test), $(n=3)$.

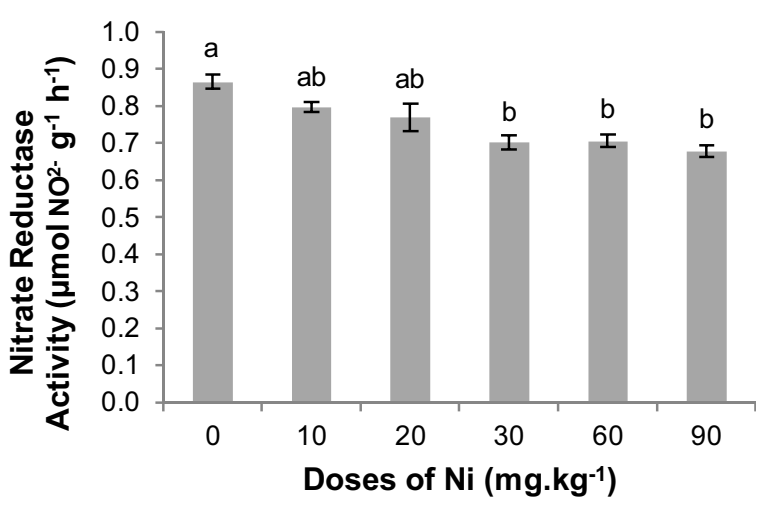

Fig. 5. Variation of the nitrate reductase activity in the fresh leaves ( $\mu \mathrm{mol} \mathrm{NO}_{2}{ }^{-}$ $\mathrm{g}^{-1} \mathrm{~h}^{-1}$ ) of lentils grown on soil contaminated with Ni. Means \pm confidence interval within columns followed by the same letter do not differ significantly according to Tukey's multiple range test $(\alpha=0.05)$. 


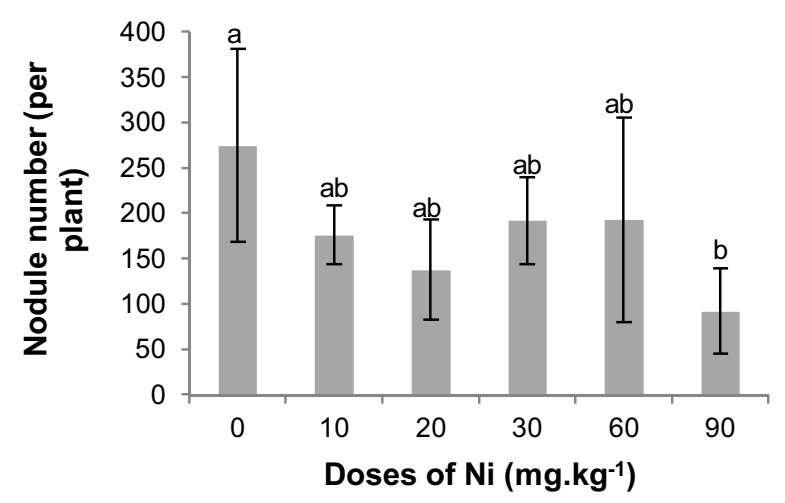

Fig. 6. Nodule number (per plant) of lentils in relation to $\mathrm{Ni}$ addtions $\left(\mathrm{mg} \mathrm{kg}^{-1}\right)$. Means \pm confidence interval followed by different letters are significantly different at $\mathrm{p}<0.05$ (Tukey's multiple range test), $(\mathrm{n}=3)$.

the control shoots, although roots did accumulate small quantities (15.1 $\mathrm{mg} \mathrm{Ni} \mathrm{kg}^{-1}$ ).

\subsubsection{Pigments and nitrate reductase activity}

A significantly higher chlorophyll concentration $\left(1.19 \mathrm{mg} \mathrm{g}^{-1}\right.$ FW) was observed in leaves of plants grown under high Ni addition ( $90 \mathrm{mg} \mathrm{Ni} \mathrm{kg} \mathrm{in}^{-1}$ comparison with the other treatments). The control was not different from other treatments (Fig. 4). The carotenoid concentration in leaves was not affected significantly by soil [Ni], but it followed the same trend as the chlorophyll getting somehow higher with the increase of [Ni] (Fig. 4). NRA decreased slightly when [Ni] in the soil increased (Fig. 5). Plants growing on soils contaminated with $30-90 \mathrm{mg} \mathrm{Ni} \mathrm{kg}^{-1}$ had significantly lower NRA $\left(0.70,0.71\right.$ and $0.68 \mu \mathrm{mol} \mathrm{NO}{ }^{-} \mathrm{g}^{-1} \mathrm{~h}^{-1}$, respectively) than the control $\left(0.87 \mu \mathrm{mol} \mathrm{NO}{ }^{-} \mathrm{g}^{-1} \mathrm{~h}^{-1}\right)$.

\subsubsection{Nodule number}

Lentil plants growing on soil with $90 \mathrm{mg} \mathrm{Ni} \mathrm{kg}^{-1}$ had significantly fewer nodules than the control $\left(0 \mathrm{mg} \mathrm{Ni} \mathrm{\textrm {kg } ^ { - 1 } )}\right.$ (Fig. 6). No significant difference was observed for this parameter for the lowest [Ni].

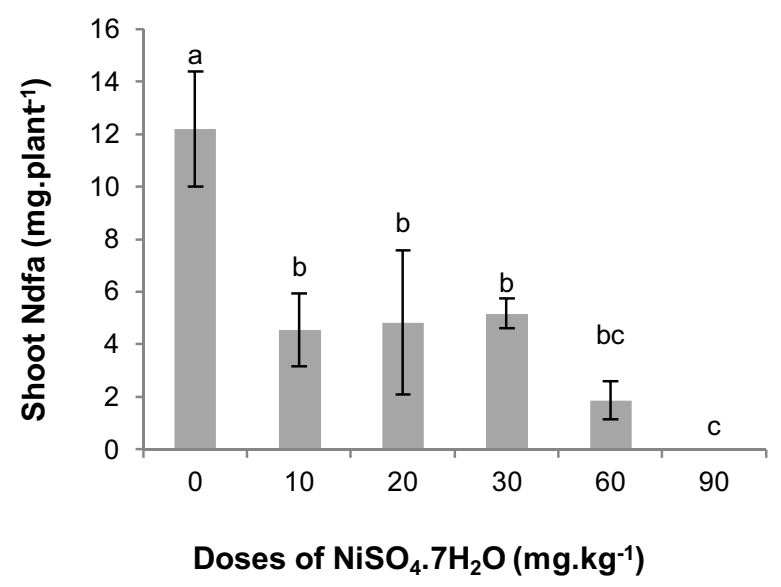

Fig. 7. Shoot nitrogen fixed from the air (Ndfa, mg plant ${ }^{-1}$ ) of lentils grown on soil contaminated with $\mathrm{Ni}$. Means \pm confidence interval followed by different letters are significantly different at $\mathrm{p}<0.05$ (Tukey's multiple range test), $(\mathrm{n}=3)$.

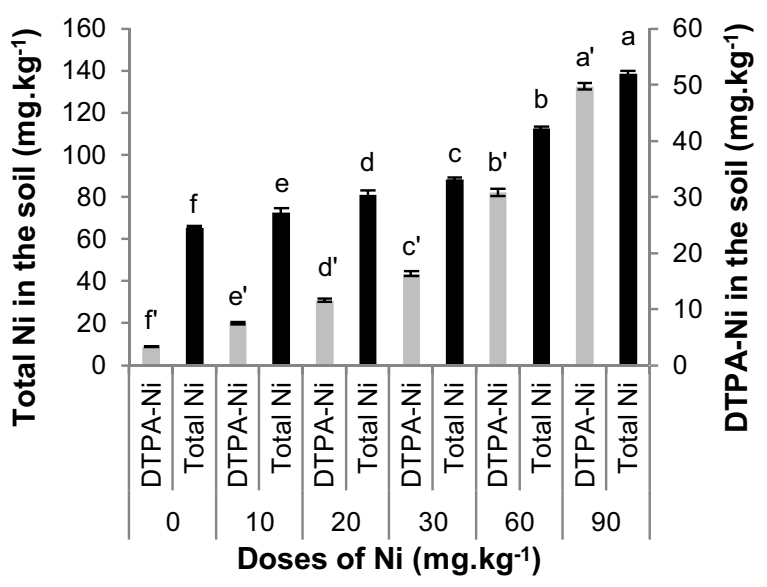

Fig. 8. Total nickel (total-Ni) (black bars) and DTPA-extractable nickel (DTPA-Ni) (grey bars) in the soil at the harvest $\left(\mathrm{mg} \mathrm{kg}^{-1}\right)$. Means \pm confidence interval followed by different letters are significantly different at $\mathrm{p}<0.05$ (Tukey's multiple range test), $(n=3)$.

\subsection{6. $\mathrm{N}_{2}$ fixation}

The amount of nitrogen fixed from the air (Ndfa) decreased when soil [Ni] increased (Fig. 7). Control soils had significantly greater Ndfa (12.2 $\mathrm{mg} \mathrm{plant}^{-1}$ ) in comparison to all other treatments. The highest [Ni] completely cancelled Ndfa $\left(0 \mathrm{mg} \mathrm{plant}^{-1}\right)$. No significant differences were shown among other [Ni] of 10,20 , 30 and $60 \mathrm{mg} \mathrm{Ni} \mathrm{kg}^{-1}$.

\subsection{Soil characteristics}

\subsubsection{Total Ni and DTPA-Ni}

Soil [Ni] supplied at the beginning of the experiment strongly structured the distribution of total Ni and DTPA-extractable nickel among the gradient of soils (Fig. 8). The total [Ni] quantified in the soil at harvest is proportional to the [Ni] supplied in the soil and reached a maximum of $138.8 \mathrm{mg} \mathrm{Ni} \mathrm{kg}^{-1}$ with the addition of

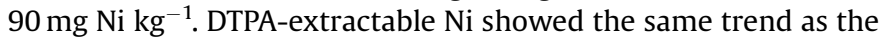
total $\mathrm{Ni}$ in the soil (also measured after harvest) and was comprised between 50 and $55 \%$ of $\mathrm{Ni}$ added and the highest addition (i.e.

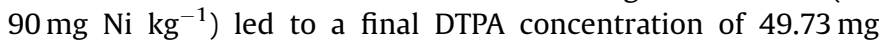
$\mathrm{Ni} \mathrm{kg}^{-1}$ (Fig. 8). The targeted concentrations observed in field conditions for further implementation of legumes (i.e. $\approx 30 \mathrm{mg}$ $\mathrm{kg}^{-1}$ ) were thus comprised in the range tested here.

\subsection{2. $\mathrm{pH}$ and $\mathrm{CEC}$}

Regardless of soil treatment, soil $\mathrm{pH}$ at harvest was significantly lower by $0.13-0.22 \mathrm{pH}$ units than the control soil (6.63) for the 60 and $90 \mathrm{mg} \mathrm{Ni} \mathrm{kg}^{-1}$ treatments, respectively (Fig. 9). In the same way, the treatment with [Ni] at $90 \mathrm{mg} \mathrm{kg}^{-1}$ had the lowest CEC, the difference with all other treatments being significant (data not shown).

\subsubsection{Soil nitrogen and carbon}

No significant differences were observed between any of the treatments for the percentage of total and organic soil $\mathrm{N}$ and $\mathrm{C}$ (data not shown). Similarly, no significant difference was detected for soluble $\mathrm{C}$ in soils (data not shown). The soluble $\mathrm{N}$ concentration in soils at harvest was the highest $\left(58.8 \mathrm{mg} \mathrm{kg}^{-1}\right)$ with addition of $90 \mathrm{mg} \mathrm{kg}^{-1}$, compared to control and other treatments (between 20.4 and $27.5 \mathrm{mg} \mathrm{kg}^{-1}$ ). There was no significant difference between control and treatments with additions from 10 to

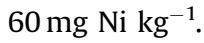




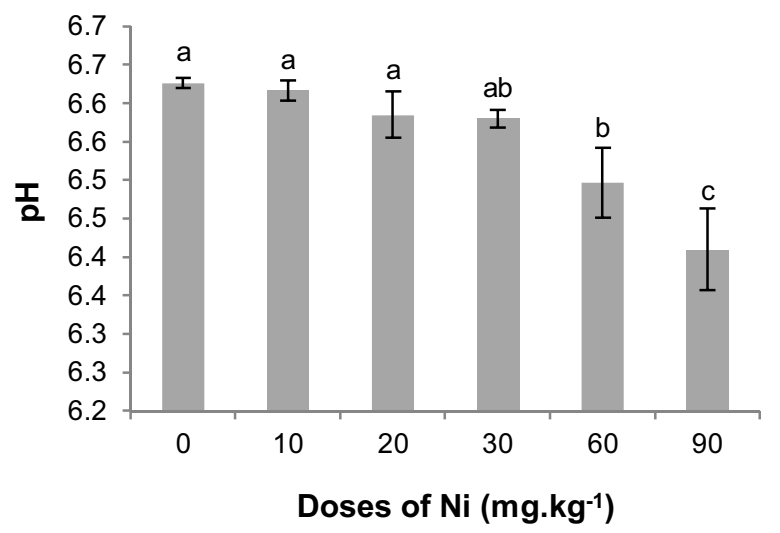

Fig. 9. $\mathrm{pH}$ of the soil at the harvest. Means \pm confidence interval followed by different letters are significantly different at $\mathrm{p}<0.05$ (Tukey's multiple range test), $(n=3)$.

\subsubsection{Ammonium and nitrate}

No ammonium was detected in soils at harvest for all treatments (data not shown). In contrast, high nitrate concentrations were measured, without significant difference among all treatments, except a higher, but non-significant, nitrate concentration for the addition of $90 \mathrm{mg} \mathrm{kg}^{-1}\left(59.7 \mathrm{mg} \mathrm{kg}^{-1}\right)$ compared to the control (34.6 $\mathrm{mg} \mathrm{kg}^{-1}$ ) (data not shown).

\section{Discussion}

Hyperaccumulators are considered to be ideal candidates for application in agromining, a non-destructive approach for the recovery of high value metals (e.g. $\mathrm{Ni}$ ) from metal-enriched soils. However agromining should focus on species showing the highest levels of hyperaccumulation. Unfortunately, the annual biomass production of some hyperaccumulator species is not sufficiently high. Therefore, high biomass yield and metal hyperaccumulation are both required in order to make agromining a commercially viable alternative (Zhang et al., 2014; van der Ent et al., 2015).

As shown in classic agricultural systems, the inclusion of a legume in inter-cropping or co-cropping provides nitrogen inputs in the cultural system in addition to producing valuable yields (Lizarazo et al., 2015). So, our objective was to investigate whether Lens culinaris could be used in inter- or co-cropping with a hyperaccumulator plant in order to improve Ni phytoextraction by hyperaccumulator plants without any chemical fertilizer input. But it is necessary to control if this legume can grow and form functional nodules within the range of natural Ni concentrations displayed by ultramafic agricultural soils. Indeed, there are numerous reports where elevated amounts of trace metals have been found to limit the growth of both rhizobia and their host legumes (Heckman et al., 1987; Broos et al., 2005) and concomitantly reduce crop yields. But, it is also known that the degree of tolerance of plants (including legumes) to trace metals have been divided into three categories: hypotolerance, basal tolerance, and hypertolerance (Ernst et al., 2008), and that some legumes can be found in different habitats polluted by excess heavy metals. For example, Anthyllis vulneraria can be found naturally in ultramafic soils and is able to fix $80 \%$ of its total nitrogen from atmosphere. The study of serpentinophytes in North-Est Portugal revealed that some families, such as legumes, showed high tolerance to serpentine soils (Menezes de Sequeira and Pinto da Silva, 1992). Different species of Trifolium (T. Bocconei, T. cherleri, T. strictum), Anthyllis sampaiana, Lotus tenuis are common in these serpentine environments. The same occurs in ultramafic soils of Albania where species of Trifolium (T. nigriscens, T. campestre, T. angustifolium) and of Lotus (L. corniculatus and $L$. angustissimus) are common species or can even be dominating species and display extremely high $\mathrm{Ni}$ concentrations in shoots, e.g. T. nigrescens (Bani et al., 2007, 2013).

In our study, lentil which was nevertheless adversely affected by the increase of soil [Ni], tolerated a moderate availability of $\mathrm{Ni}$, from 7.5 to $30.8 \mathrm{mg} \mathrm{Ni}-\mathrm{DTPA} \mathrm{kg} \mathrm{k}^{-1}$ (corresponding to additions of $10-60 \mathrm{mg} \mathrm{Ni} \mathrm{kg}^{-1}$ ) based on results of plant biomass weight, $\mathrm{C}$ and $\mathrm{N}$ content, physiological parameters and nodule numbers. Trace metals contaminated soils severely affects the survival of Rhizobium strains as described by Gusmão et al. (2005). Rhizobia strains isolated from Lens culinaris revealed the lowest resistance to trace metals, in comparison to other strains isolated from different nodulated legumes (Vicia faba, Cicer arietinum and Sulla coronaria), when tested on culture media enriched with trace metals $(\mathrm{Cd}, \mathrm{Pb}$, $\mathrm{Zn}$ and $\mathrm{Cu}$ ) (Fatnassi et al., 2014). This fact explains the reduced atmospheric $\mathrm{N}_{2}$ fixation in our study that could be related to a decreased symbiotic activity of the microbes at the highest soil $\mathrm{Ni}$ availability. These outcomes affected various parameters such as the Ndfa, but also the shoot biomass, which was also negatively correlated to $\mathrm{Ni}$ additions to the soil. Moreover, shoots and roots of enriched treatments accumulated greater [Ni], which was also positively correlated to Ni-DTPA concentrations, total and exchangeable $\mathrm{Ni}$ in soils at harvest. Such accumulation of $\mathrm{Ni}$ in plant parts is known to cause a reduction of the plant biomass (Ahmad et al., 2012) and roots stored a higher amount of Ni than shoots, as reported by previous studies on legumes (Roy et al., 2009). As a result of the decreased $\mathrm{Ndfa}$, the ${ }^{15} \mathrm{~N}$ excess in lentil and the proportion of nitrogen content in lentil coming from the seed (data not shown) increased when [Ni] rose from 0 to $90 \mathrm{mg} \mathrm{kg}^{-1}$. At the latter concentration there was absolutely no more $\mathrm{N}$ input to the system from atmospheric $\mathrm{N}_{2}$ fixation, thus making the potential association with hyperaccumulators non profitable in terms of $\mathrm{N}$ budget (competition for $\mathrm{N}$ absorption between both species).

Physiologically and more precisely, [Ni] showed direct and indirect toxic effects on the various plant processes, which were monitored in this study. We followed the effect of [Ni] on pigments concentrations in leaves, but we eventually found that carotenoids were not significantly affected by the increase of [Ni] in the soil. However, Ni had a contradictory effect on chlorophyll content in leaves. It is known that trace metals have a negative effect on chlorophyll content in plants (Zengin and Munzuroglu, 2005; Fatoba et al., 2008). Our hypothesis regarding the increase of the chlorophyll content in fresh leaves at highest Ni concentrations was that reduction of plant biomass results in a mechanical concentration of chlorophyll in leaves (Krupa et al., 1993; Prasad and Freitas, 2003). Nickel added to the soil deleteriously affected nitrate reductase activity (NRA) in shoots. Reduction of NRA, due to the inhibition of nitrate translocation from roots to shoots by $\mathrm{Ni}$, has also been reported in many previous studies (e.g. Kevrešan et al., 1998; Sharma and Subhadra, 2010). Consequently, decreased amounts of leaf nitrate implied lower NRA levels (Kevrešan et al. 1998), which were also affected by the photosynthetic process (Bazzigalupi et al., 1992). Metabolites issued from the photosynthetic metabolism are essential to nitrate reduction. Therefore, photosynthesis, related at the same time to leaf size and chlorophyll quantities, was limited, thus decreasing both the uptake and reduction of nitrate (Bazzigalupi et al., 1992).

Nitrogen and carbon in the shoots were also significantly reduced by the $\mathrm{Ni}$ concentrations in the soil. Strong positive correlations linked $\mathrm{C}$ and $\mathrm{N}$ contents in shoots to shoot biomass and to Ndfa in shoots (Pearson correlations, 0.982 and 0.878 respectively; data not shown). It is known that high concentrations of metals limit nutrient and water uptake from the soil and thus reduce biomass production and dry matter accumulation in shoots 
and roots. Furthermore, the photosynthesis, carbohydrate and protein synthesis are also reduced due to the induced oxidative stress by the heavy metal (Ahmad et al., 2012). Both, nitrogen fixed from the air and nitrate assimilation from the soil, reported to be reduced by the heavy metal toxicity, to diminish nitrogen content in both shoots and roots (Ahmad et al., 2012).

No ammonium concentrations were detected in our soil. This was due to the main conversion of ammonia in soil into nitrate through nitrification (Robertson 1997). In general, ammonium is found in lower amounts in soils than nitrate (Burger and Jackson, 2003).

Soil pH and CEC decreased with increasing soil-Ni concentrations and this was probably due to the complexation of $\mathrm{Ni}^{2+}$ to soil surface sites and to the $\mathrm{Ni}^{2+}$ exchange with other cations from CEC, in both cases releasing surface $\mathrm{H}^{+}$ions. Furthermore, the stability of Ni sorbed onto organic particles and the polymerization of cation-bound organic matter diminished the CEC in the soil at high Ni concentrations (Violante et al., 2010). The soluble $\mathrm{N}$ pool in the soil and nitrate ions were reversely affected by increasing concentrations of $\mathrm{Ni}$ due to the reduced ability of the lentils to absorb nutrients at higher Ni concentrations (Ahmad et al., 2012). On one hand, we agree with this comment but on the other hand, it is never possible to assess one single factor in studying serpentine stress by using serpentine soils which combine all stresses in one. This is why we based the study on DTPA-Ni on a soil that we anticipated thinking that it had a $\mathrm{pH}$ value close to neutrality to avoid any $\mathrm{pH}$ effect. Indeed, the $\mathrm{pH}$ values after cropping were slightly higher (which by the way might explain the slight decrease in DTPA-Ni) but comprised between 6.5 and 6.7 (considered as neutral $\mathrm{pH}$ ). Our interest was the level of DTPA-Ni the plant was exposed to having all chemical fertility parameters in optimal conditions, so that we could have an idea of what the Ni stress is on the legume. The level of stress was still significant, although many serpentine soils may exceed this DTPA-Ni value in topsoils. So we can question that idea that $\mathrm{Ni}$ in serpentine is not the stressing factor. We agree, but here we used an agricultural soil which is normally fertile and all studied parameters confirm the phytotoxic effect of $\mathrm{Ni}$ on lentil even if the soil $\mathrm{pH}$ was neutral.

In natural ultramafic soils stresses to crop plants are linked to i) the low fertility of these soils, ii) the toxicity of $\mathrm{Ni}$ and, iii) the high ratio of Mg:Ca (Whittaker, 1954; Proctor and Woodell 1975; Brooks, 1987). The two last stresses can be overcome by an adapted chemical fertilization pattern, but it is more difficult to change $\mathrm{Ni}$ availability, even with limestone additions (Kukier and Chaney, 2004). Our experience is that DTPA-Ni and water-soluble $\mathrm{Ni}$ in temperate ultramafic soils are still high enough to cause toxicity symptoms to non-adapted plants at $\mathrm{pH}$ values below 8.0. This is because the mineral phases that bear $\mathrm{Ni}$ are moderately sensitive to $\mathrm{pH}$ at this range of values, i.e. below 8.0 (Massoura et al., 2006; Bani et al., 2014; Raous et al., 2013). Raising the pH value of 1 unit by liming to substantially decrease $\mathrm{Ni}$ availability cannot be achieved without any negative side effect on $\mathrm{P}$ and $\mathrm{K}$ availability and requires further fertilizer input, thus becoming an economic issue. Although liming has been proven to be beneficial to $\mathrm{Ni}$ phytoextraction yield by $A$. murale (Kukier and Chaney, 2004), it can be expensive and can increase Ca concentrations in shoots, thus increasing the cost of hydrometallurgical treatment of the biomass for Ni recovery (Zhang et al., 2016).

We demonstrated that lentils can tolerate strong concentrations of Ni-DTPA in the soil and it was previously reported that lentils are able to tolerate high concentrations of trace metals, such as copper, lead and cadmium (Fatnassi et al., 2014). The lentils can withstand a wide range of DTPA-Ni concentrations in the soil (up to

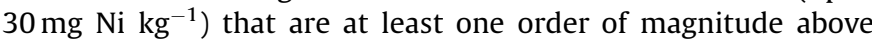
acceptable levels for most crops (L'Huillier and Edighoffer, 1996). This range of concentrations is frequently observed in naturally rich ultramafic soil although slightly lower than many ultramafic soils (Bani et al., 2009, 2013). Therefore, the naturally ultramafic soils, which will be used in further experiments to test the association of Lens culinaris with a hyperaccumulator plant under co-cropping or in rotation, display DTPA-Ni concentrations which are comprised in our tested range and the plant should be successfully cropped in field conditions provided that $\mathrm{Ca}, \mathrm{K}$ and $\mathrm{Mg}$ fertility issues are managed.

\section{Conclusion}

Our study confirmed that lentils can tolerate relatively high concentrations of available nickel in the soil (i.e. 6 times higher than background values found in non ultramafic soils), although a physiological stress is induced with additions of $\mathrm{Ni}$ above $60 \mathrm{mg}$ $\mathrm{kg}^{-1}$. Lentils can still produce nodules that fix nitrogen from the air for most of the range of $\mathrm{Ni}$ additions tested although the number of nodules is strongly affected by $\mathrm{Ni}$ additions. Nitrogen fixation is also affected in the same way and becomes null when available concentrations of Ni reach $49.7 \mathrm{mg} \mathrm{kg}^{-1}$ DTPA-Ni. The quantity of available $\mathrm{Ni}$ found in the serpentine soil, which will be used in the future work, is within the range of the concentrations investigated in this experiment (i.e. $30 \mathrm{mg} \mathrm{kg}^{-1} \mathrm{Ni}$-DTPA). Our upcoming work will be to test Lens culinaris in inter- or co-cropping with a hyperaccumulator plant to enhance its biomass production by providing nitrogen and to allow this hyperaccumulator to extract more $\mathrm{Ni}$, however, the potential association with hyperaccumulators will become non profitable in terms of $\mathrm{N}$ budget (competition for $\mathrm{N}$ absorption between both species) if we exceed a value of $30 \mathrm{mg} \mathrm{kg}^{-1} \mathrm{Ni}-\mathrm{DTPA}$.

\section{Acknowledgment}

We would like to acknowledge the technical team of "Laboratoire Sols et Environnement" for their help and support and the technical assistance of the joint research unit Forest Ecology and Ecophysiology (UMR 1127 INRA, EEF, Champenoux), and especially Christian HOSSANN for the isotopic analysis of ${ }^{15} \mathrm{~N}$. This work was supported by the French National Research Agency through the national "Investissements d'avenir" program, reference ANR-10-LABX-21-LABEX RESSOURCES21 and through the ANR-14-CE04-0005 project "Agromine". Finally, we are thankful to the Association of Specialization and Scientific Guidance (ASSG) for funding the PhD scholarship of Ramez Saad.

\section{References}

Abeles, F.B., Morgan, P.W., Saltveit Jr., M.E., 1992. Chapter 4-Regulation of ethylene production by internal, environmental, and stress factors, In: Saltveit Jr., M.E. (Ed.), Ethylene in Plant Biology. second edition Academic Press, New York, pp. 56-119. doi:http://dx.doi.org/10.1016/B978-0-08-091628-6. 50010-2.

Ahmad, M.S.A., Hussain, M., Ijaz, S., Alvi, A.K., 2008. Photosynthetic performance of two mung bean (Vigna radiata) cultivars under lead and copper stress. Int. J. Agric. Biol. 10, 167-172.

Ahmad, E., Zaidi, A., Khan, M., Oves, M., 2012. Heavy metal toxicity to symbiotic nitrogen-fixing microorganism and host legumes. In: Zaidi, A., Wani, P.A., Khan, M.S. (Eds.), Toxicity of Heavy Metals to Legumes and Bioremediation. Springer, Vienna, pp. 29-44. doi:http://dx.doi.org/10.1007/978-3-7091-0730-0-2.

Amarger, N., Mariotti, A., Mariotti, F., Durr, J.C., Bourguignon, C., Lagacherie, B., 1979 Estimate of symbiotically fixed nitrogen in field grown soybeans using variations in ${ }^{15} \mathrm{~N}$ natural abundance. Plant Soil 52, 269-280. doi:http://dx.doi. org/10.1007/BF02184565.

Arnon, D.I., 1949. Copper enzymes in isolated chloroplasts: polyphenoloxidase in Beta vulgaris. Plant Physiol. 24, 1-15.

Bani, A., Echevarria, G., Sulçe, S., Morel, J.L., Mullai, A., 2007. In-situ phytoextraction of Ni by a native population of Alyssum murale on an ultramafic site (Albania). Plant Soil 293, 79-89. doi:http://dx.doi.org/10.1007/s11104-007-9245-1.

Bani, A., Echevarria, G., Mullaj, A., Reeves, R.D., Morel, J.L., Sulçe, S., 2009. Nickel hyperaccumulation by Brassicaceae in serpentine soils of Albania and Northwest Greece. Northeast. Nat. 16, 385-404. 
Bani, A., Imeri, A., Echevarria, G., Pavlova, D., Reeves, R.D., Morel, J.L., Sulçe, S., 2013. Nickel hyperaccumulation in the serpentine flora of Albania. Fresen. Environ. Bull. 22, 1792-1801.

Bani, A., Echevarria, G., Montargès-Pelletier, E., Gjoka, F., Sulçe, S., Morel, J.L., 2014 Pedogenesis and nickel biogeochemistry in a typical Albanian ultramafic toposequence. Environ. Monit. Assess. 186, 4431-4442. doi:http://dx.doi.org/ 10.1007/s10661-014-3709-6.

Bani, A., Echevarria, G., Sulçe, S., Morel, J.L., 2015a. Improving the agronomy of Alyssum murale for extensive phytomining: a five-year field study. Int. J. Phytoremediat. 17, 117-127. doi:http://dx.doi.org/10.1080/ 15226514.2013 .862204

Bani, A., Echevarria, G., Zhang, X., Benizri, E., Laubie, B., Morel, J.L., Simonnot, M.-O., 2015b. The effect of plant density in nickel-phytomining field experiments with Alyssum murale in Albania. Aust. J. Bot. 63, 72-77.

Bazzigalupi, O., Deroche, M.E., Lescure, J.C., Bachelier, C., Tardif, S., 1992. Activité nitrate réductase in vitro de jeunes plantules de blé (Triticum aestivum L.) cultivées dans les conditions de détermination de la faculté germinative et après amélioration de la nutrition et de l'éclairement. Agronomie 12, 711-721.

Berazaín, R., 2007. Nickel localization in tissues of different hyperaccumulator species of Euphorbiaceae from ultramafic areas of Cuba. Plant Soil 293, 99-106. doi:http://dx.doi.org/10.1007/s11104-007-9227-3.

Bibi, M., Hussain, M., 2005. Effect of copper and lead on photosynthesis and plant pigments in black gram (Vigna mungo L.). Bull. Environ. Contam. Toxicol. 74, 1126-1133. doi:http://dx.doi.org/10.1007/s00128-005-0698-8.

Boyd, R.S., Jaffré, T., 2009. Elemental concentrations of eleven New Caledonian plant species from serpentine soils: elemental correlations and leaf-age effects. Northeast. Nat. 16, 93-110. doi:http://dx.doi.org/10.1656/045.016.0508.

Brahima, S., Jokea, D., Ann, C., Jean-Paul, N., Marjo, T., Arja, T., Sirpac, K., Frank, V., Karen, S., Jaco, V., 2010. Leaf proteome responses of Arabidopsis thaliana exposed to mild cadmium stress. J. Plant Physiol. 167, 247-254. doi:http://dx.doi.org/ 10.1016/j.jplph.2009.09.015.

Brooks, R.R., 1987. Serpentine and Its Vegetation: A Multiclisciplinary Approach. Discoides Press, Kent, UK.

Broos, K., Beyens, H., Smolders, E., 2005. Survival of rhizobia in soil is sensitive to elevated zinc in the absence of the host plant. Soil Biol. Biochem. 37, 573-579.

Burger, M., Jackson, L.E., 2003. Microbial immobilization of ammonium and nitrate in relation to ammonification and nitrification rates in organic and conventional cropping systems. Soil Biol. Biochem. 35, 29-36. doi:http://dx.doi.org/10.1016/ S0038-0717(02)00233-X.

Chaney, R.L., Angle, J.S., Broadhurst, C.L., Peters, C.A., Tappero, R.V., Sparks, D.L., 2007. Improved understanding of hyperaccumulation yields commercial phytoextraction and phytomining technologies. J. Environ. Qual. 36, 1429-1443.

Chaney, R.L., Chen, K.Y., Li, Y.M., Angle, J.S., Baker, A.J.M., 2008. Effects of calcium on nickel tolerance and accumulation in Alyssum species and cabbage grown in nutrient solution. Plant Soil 311,131-140. doi:http://dx.doi.org/10.1007/s11104008-9664-7.

Echevarria, G., Baker, A.J.M., Bani, A., Benizri, E., Houzelot, V., Laubie, B., Kidd, P.S., Morel, J.L., Pons, M.N., Simonnot, M.O., van der Ent, A., Zhang, X., 2015. Agromining for nickel: a complete chain that optimizes ecosystem services rendered by ultramafic landscapes. 13th International Conference on the Biogeochemistry of Trace Elements (ICOBTE), July 12-16, pp. 2015.

Ernst, W.H.O., Krauss, G.J., Verklej, J.A.C., Wesenberg, D., 2008. Interaction with heavy metals with the sulphur metabolism in angiosperms from an ecological point of view. Plant Cell. Environ. 31, 123-143.

Fatnassi, I.C., Chiboub, M., Jebara, M., Jebara, S.H., 2014. Bacteria associated with different legume species grown in heavy-metal contaminated soils. Int. J. Agric. Policy Res. 2, 460-467. doi:http://dx.doi.org/10.15739/IJAPR.018.

Fatoba, P.O., Udob, P.O., Emem, G., 2008. Effects of some heavy metals on chlorophyll accumulation in Barbula lambarenensis. Ethnobotanical Leaflets 12, 776-783.

Fustec, J., Lesuffleur, F., Mahieu, S., Cliquet, J.B., 2010. Nitrogen rhizodeposition of legumes. A review. Agron. Sustainable Dev. 30, 57-66. doi:http://dx.doi.org/ 10.1051 /agro/2009003.

Glick, B.R., 2005. Modulation of plant ethylene levels by the bacterial enzyme ACC deaminase. FEMS Microbiol. Lett. 251, 1-7. doi:http://dx.doi.org/10.1016/j. femsle.2005.07.030.

Glick, B.R., 2014. Bacteria with ACC deaminase can promote plant growth and help to feed the world. Microbiol. Res. 169, 30-39. doi:http://dx.doi.org/10.1016/j. micres.2013.09.009

Gusmão, L.A.I., Figueira, E., De Almeida, M.P., Pereira, S.I.A., 2005. Cadmium tolerance plasticity in Rhizobium leguminosarum bv. viciae: glutathione as a detoxifying agent. Can. J. Microbiol. 51, 7-14.

Högberg, P., 1997. Tansley review No $95{ }^{15} \mathrm{~N}$ natural abundance in soil-plant systems. New Phytol. 137, 179-203. doi:http://dx.doi.org/10.1046/j.14698137.1997.00808.x.

Heckman, J.R., Angle, J.S., Chaney, R.L., 1987. Residual effects of sewage sludge on soybean II. Accumulation of soil and symbiotically fixed nitrogen. J. Environ. Qual. 16, 117-124.

Hirsch, A.M., Fang, Y.W., 1994. Plant hormones and nodulation - whats the connection. Plant Mol. Biol. 26, 5-9. doi:http://dx.doi.org/10.1007/bf00039514.

Jaworski, E.G., 1971. Nitrate reductase assay in intact plant tissues. Biochem. Biophys. Res. Commun. 43, 1274-1279.

Kabata-Pendias, A., 2000. Trace elements in soils and plants. CRC Press, Boca Raton, USA (432 pp).

Kerley, S.J., Jarvis, S.C., 1999. The use of nitrogen-15 natural abundance in white clover (Trifolium repens L.) to determine nitrogen fixation under different management practices. Biol. Fertil. Soils 29, 437-440. doi:http://dx.doi.org/ 10.1007/s003740050578.

Kevrešan, S., Petrović, N., Popović, M., Kandrač, J., 1998. Effect of heavy metals on nitrate and protein metabolism in sugar beet. Biol. Plantarum. 41, 235-240. doi: http://dx.doi.org/10.1023/A:1001818714922.

Kidd, P., Mench, M., Álvarez-López, V., Bert, V., Dimitriou, I., Friesl-Hanl, W., Herzig, R., Janssen, J.-O., Kolbas, A., Müller, I., Neu, S., Renella, G., Ruttens, A., Vangronsveld, J., Puschenreiter, M., 2015. Agronomic practices for improving gentle remediation of trace element-contaminated soils. Int. J. Phytoremediat. 17, 1005-1037. doi:http://dx.doi.org/10.1080/15226514.2014.1003788.

Krupa, Z., Siedlecka, A., Maksymiec, W., Baszyilski, T., 1993. In vivo response of photosynthetic apparatus of Phaseolus vulgaris L. to nickel toxicity. J. Plant Physiol. 142, 664-668. doi:http://dx.doi.org/10.1016/S0176-1617(11)80899-0.

Kukier, U., Chaney, R., 2004. In situ remediation of nickel phytotoxicity for different plant species. J. Plant Nutr. 27, 465-495. doi:http://dx.doi.org/10.1081/PLN120028874.

L'Huillier, L., Edighoffer, S., 1996. Extractability of nickel and its concentration in cultivated plants in Ni-rich ultramafic soils of New Caledonia. Plant Soil 186 255-264. doi:http://dx.doi.org/10.1007/BF02415521.

Lee, K.H., Larue, T.A., 1992. Exogenous ethylene inhibits nodulation of Pisum sativum L. cv sparkle. Plant Physiol. 100, 1759-1763.

Ligero, F., Caba, J.M., Lluch, C., Olivares, J., 1991. Nitrate inhibition of nodulation can be overcome by the ethylene inhibitor aminoethoxyvinylglycine. Plant Physiol. 97, 1221-1225.

Lindsay, W.L., Norvell, W.A., 1978. Development of a DTPA soil test for zinc, iron, manganese, and copper. Soil Sci. Soc. Am. J. 42, 421-428. doi:http://dx.doi.org/ 10.2136/sssaj1978.03615995004200030009x.

Lizarazo, C.I., Yli-Halla, M., Stoddard, F.L., 2015. Pre-crop effects on the nutrient composition and utilization efficiency of faba bean (Vicia faba L.) and narrowleafed lupin (Lupinus angustifolius L.). Nutr. Cycl. Agroecosys. 103, 311-327. doi: http://dx.doi.org/10.1007/s10705-015-9743-0.

Luce, M.St., et al., 2015. Legumes can reduce economic optimum nitrogen rates and increase yields in a wheat-canola cropping sequence in western Canada. Field Crops Res. 179, 12-25. doi:http://dx.doi.org/10.1016/j.fcr.2015.04.003.

Massoura, S.T., Echevarria, G., Becquer, T., Ghanbaja, J., LeclercCessac, E., Morel, J.-L., 2006. Control of nickel availability by nickel bearing minerals in natural and anthropogenic soils. Geoderma 136, 28-37.

Menezes de Sequeira, E., Pinto da Silva, A.R., 1992. Ecology of serpentinized area of North-East Portugal. In: Roberts, B.A., Proctor, J. (Eds.), The Ecology of Areas with Serpentinized Rocks: A World View. KluwerDordrecht, pp. 169-197.

Mokgehle, S.N., Dakora, F.D., Mathews, C., 2014. Variation in $\mathrm{N}_{2}$ fixation and $\mathrm{N}$ contribution by 25 groundnut (Arachis hypogaea L.) varieties grown in different agro-ecologies, measured using ${ }^{15} \mathrm{~N}$ natural abundance. Agric. Ecosyst. Environ. 195, 161-172. doi:http://dx.doi.org/10.1016/j.agee.2014.05.014.

Munns, D.N., 1977. Mineral nutrition and the legume symbioses. A Treatise on Dinitrogen Fixation. Section IV. Wiley, New York, pp. 353-391.

Nyagumbo, I., Mkuhlani, S., Pisa, C., Kamalongo, D., Dias, D., Mekuria, M., 2015. Maize yield effects of conservation agriculture based maize-legume cropping systems in contrasting agro-ecologies of Malawi and Mozambique. Nutr. Cycl. Agroecosys. doi:http://dx.doi.org/10.1007/s10705-015-9733-2.

Peoples, M.B., Chalk, P.M., Unkovich, M.J., Boddey, R.M., 2015. Can differences in ${ }^{15} \mathrm{~N}$ natural abundance be used to quantify the transfer of nitrogen from legumes to neighbouring non-legume plant species? Soil Biol. Biochem. 87, 97-109. doi: http://dx.doi.org/10.1016/j.soilbio.2015.04.010.

Prasad, M.N.V., Freitas, H.M.D., 2003. Metal hyperaccumulation in plantsbiodiversity prospecting for phytoremediation technology. Electron. J. Biotechnol. 93, 285-321.

Proctor, J., Woodell, S.R.J., 1975. The ecology of serpentine soils. Adv. Ecol. Res. 9, 255-366.

Raous, S., Echevarria, G., Sterckeman, T., Hanna, K., Thomas, F., Martins, E.S., Becquer, T., 2013. Potentially toxic metals in ultramafic mining materials: identification of the main bearing and reactive phases. Geoderma 192, 111-119. doi:http://dx. doi.org/10.1016/j.geoderma.2012.08.017.

Robertson, P.G., 1997. Nitrogen use efficiency in row-crop agriculture: crop nitrogen use and soil nitrogen loss. Ecology in Agriculture. Academic Press, San Diego, pp. 347-365.

Rodrigues, M., Dimande, P., Pereira, E.L., Ferreira, O.I., Freitas, S., Correia, C.M., Moutinho-Pereira, J., Arrobas, M., 2015. Early-maturing annual legumes: an option for cover cropping in rainfed olive orchards. Nutr. Cycl. Agroecosys. 103 153-166. doi:http://dx.doi.org/10.1007/s10705-015-9730-5.

Roy, B.K., Prasad, R., Gunjan, R., 2009. Heavy metal accumulation and changes in metabolic parameters in Cajanus cajan grown in mine spoil. J. Environ. Biol. 31, 567-573.

Scalise, A., Tortorella, D., Pristeri, A., Petrovičová, B., Gelsomino, A., Lindström, K., Monti, M., 2015. Legume-barley intercropping stimulates soil N supply and crop yield in the succeeding durum wheat in a rotation under rainfed conditions. Soil Biol. Biochem. 89, 150-161. doi:http://dx.doi.org/10.1016/j.soilbio.2015.07.003.

Sharma, J., Subhadra, A.V., 2010. The effect of Mercury on nitrate reductase activity in bean leaf segments (Phaseolus vulgaris) and its chelation by phytochelatin synthesis. Life Sci. Med. Res. (LSMR) 13.

Tang, Y.T., Deng, T.H.B., Wu, Q.H., Wang, S.Z., Qiu, R.L., Wei, Z.B., Guo, X.F., Wu, Q.T., Lei, M., Chen, T.B., 2012. Designing cropping systems for metal-contaminated sites: a review. Pedosphere 22, 470-488.

Tumi, A.F., Mihailovic, N., Gajic, B.A., Niketic, M., Tomovic, G., 2012. Comparative study of hyperaccumulation of nickel by Alyssum murale: populations from the ultramafics of Serbia. Pol. J. Environ. Stud. 21, 1855-1866. 
Violante, A., Cozzolino, V., Perelomov, L., Caporale, A.G., Pigna, M., 2010. Mobility and bioavailability of heavy metals and metalloids in soil environments. J. Soil Sci. Plant. Nutr. 10, 268-292. doi:http://dx.doi.org/10.4067/S071895162010000100005.

Whittaker, R.H., 1954. The ecology of serpentine soils. Ecology 35, 258-288. doi: http://dx.doi.org/10.2307/1931126.

Zengin, F.K., Munzuroglu, O., 2005. Effects of some heavy metals on content of chlorophyll, proline and some antioxidant chemicals in bean (Phaseolus vulgaris) seedlings. Acta Biol. Cracov. Ser. Bot. 47, 157-164.

Zhang, X., Houzelot, V., Bani, A., Morel, J.L., Echevarria, G., Simonnot, M.O., 2014. Selection and combustion of Ni-hyperaccumulators for the phytomining process. Int. J. Phytoremdiat. 16, 1058-1072. doi:http://dx.doi.org/10.1080/ 15226514.2013.810585.
Zhang, X., Laubie, B., Houzelot, V., Plasari, E., Echevarria, G., Simonnot, M.-O., 2016. Increasing purity of ammonium nickel sulfatehexahydrate and production sustainability in anickel phytomining process. Chem. Eng. Res. Des. 106, 26-32. doi:http://dx.doi.org/10.1016/j.cherd.2015.12.009.

van der Ent, A., Baker, A.J.M., Reeves, R.D., Pollard, A.J., Schat, H., 2013.

Hyperaccumulators of metal and metalloid trace elements: facts and fiction. Plant Soil 362, 319-334.

van der Ent, A., Baker, A.J.M., Reeves, R.D., Chaney, R.L., Anderson, C.W.N., Meech, J. A., Erskine, P.D., Simonnot, M.O., Vaughan, J., Morel, J.L., Echevarria, G., Fogliani, B., Rongliang, Q., Mulligan, D.R., 2015. Agromining: farming for metals in the future? Environ. Sci. Technol. 49, 4773-4780. doi:http://dx.doi.org/10.1021/ es506031u. 